Article

\title{
Stakeholder Perspectives to Prevent Soil Organic Matter Decline in Northeastern Italy
}

\author{
Nicola Dal Ferro ${ }^{1, *}\left(\mathbb{D}\right.$, Carlo Camarotto $^{1}\left(\mathbb{D}\right.$, Ilaria Piccoli ${ }^{1}\left(\mathbb{D}\right.$, Antonio Berti $^{1}$, Jane Mills ${ }^{2}$ and \\ Francesco Morari ${ }^{1} \mathbb{D}$
}

1 Department of Agronomy, Food, Natural resources, Animals and Environment, University of Padova, 35020 Legnaro, Italy; carlo.camarotto@unipd.it (C.C.); ilaria.piccoli@unipd.it (I.P.); antonio.berti@unipd.it (A.B.); francesco.morari@unipd.it (F.M.)

2 Countryside and Community Research Institute, University of Gloucestershire, Gloucester GL2 9HW, UK; jmills@glos.ac.uk

* Correspondence: nicola.dalferro@unipd.it; Tel.: +39-049-827-2818

Received: 19 November 2019; Accepted: 31 December 2019; Published: 2 January 2020

check for updates

\begin{abstract}
A transition from conventional to more sustainable soil management measures (SMMs) is required to reverse the current soil organic matter (SOM) losses in the agroecosystems. Despite the innovations and technologies that are available to prevent SOM decline, top-down knowledge transfer schemes that incentivize a certain measure are often ineffective. Here, we discuss relevant outcomes from a participatory approach where researchers, farmers, practitioners and government officials have discussed opportunities and barriers around SMM application to prevent SOM decline. Within a series of workshops, stakeholders identified, scored, and selected SMMs to field-tests and evaluated the benefits and drawbacks from their application. Results showed that the stakeholders recognized the need for innovations, although they valued the most promising SMM as already available continuous soil cover and conservation agriculture. In contrast, more innovative SMMs, such as biochar use and the variable rate application of organic amendments through precision farming, were the least valued, suggesting that people's resistance to new technologies is often governed by the socio-cultural perception of them that goes beyond the economic and technological aspects. The valuation of benefits and drawbacks by stakeholders on trialed measures emphasized that stakeholders' perspective about soil management is a combination of economic, environmental, and socio-cultural aspects, thus corroborating the need for transdisciplinary bottom-up approaches to prevent SOM depletion and increase soil rehabilitation and SOM content.
\end{abstract}

Keywords: Agroecosystem; land degradation; participatory approach; stakeholder involvement; sustainable soil management.

\section{Introduction}

Soil organic matter (SOM) plays a major role in maintaining soil functions because of its multiple effects on improving soil structure, retaining water and nutrients, regulating the carbon balance, and mitigating GHGs (greenhouse gases) emissions [1]. It has been estimated that around $45 \%$ of mineral soils across Europe have low or very low SOM, quantified as soil organic carbon content (i.e., the prime element of SOM, approximately $48-58 \%$ of the total weight) in the range of $0-2 \%$ [2], as a consequence of natural low fertility and major changes in land use and management [3]. The dynamics of SOM stock changes have been widely studied in the last two decades, placing the importance for its preservation on both science and policy agendas [4,5]. Currently, a lot of attention is being given to SOM in environmental policy at all geographical levels. Quantifying the dynamics of SOM content has been recently proposed as an integrative indicator of land degradation because it is able to simultaneously 
cover both diverse and vital soil chemical, physical and biological processes [6]. Furthermore, it has been adopted by the United Nations for the implementation of Sustainable Development Goals (SDGs) [7]. During the 21st Conference of the Parties to the United Nations Framework Convention on Climate Change that was held in Paris, the French Minister of Agriculture launched the 4 per 1000 initiative, which aspires to increase the global SOM by $0.4 \%$ per year, underlying the prominent place for SOM maintenance in the EU (European Union) common agricultural policy through Good Agricultural and Environmental Conditions (GAEC) requirements [8]. In this context, many regions across EU Member States have adopted diverse measures for maintaining or improving SOM according to GAEC requirements, firstly established by Council Regulation No. 1782/2003 and following Council Regulation (EC) No 73/2009: For instance, efforts have been made in some Italian regions (e.g., Veneto, Lombardy, NUTS2) [9]. Solutions for sustainable agricultural practices that lead to soil improvements (and also SOM increases) are also being pursued by large companies, such as the World Business Council for Sustainable Development, which nowadays recognizes good land condition as a prerequisite for sustainable and successful business in the long term.

Traditional methods to foster sustainable soil management measures (SMMs) have traditionally been addressed with the use of a top-down scheme, where initiatives are coordinated by governments or government-funded advisers that incentivize a certain measure through, as an example, an agri-environmental scheme. These practices are common in projects with a primarily public benefit [10], particularly in cases where degraded conditions are far from being easily recognized by land managers, such as for the decline in SOM content [11]. However, recent research has highlighted that unsustainable resource management cannot easily be solved by top-down knowledge transfer, from theory to practice [12]. As a result, bottom-up schemes have been implemented where community involvement is put into practice by combining environmental, economic and social aspects $[13,14]$. Since landscape users and interests mainly involve local populations and stakeholders [15], it is essential for specific geographical contexts to be taken into consideration in order to target best management solutions that combine effectiveness, acceptance and, finally, application [16].

In the lowlands of northeastern Italy, the loss of SOM and of fertility in mineral soils is one of the most dangerous soil threats. Agricultural intensification has led to the oversimplification of cropping systems and the uncoupling of crop and livestock production, deteriorating soil quality. Moreover, the shallow groundwater table $(<5 \mathrm{~m})$ affects agroecosystems, making soil protection even more crucial due to the strong soil-water interaction as affected by excessive nutrients and pesticide leaching. Therefore, promising SMMs are required to enhance SOM in this region. However, it is unclear what drives the successful or unsuccessful application of SMMs and the relative importance of stakeholder perceptions of environmental economic and socio-cultural factors in their implementation.

In this context, the RECARE project (Preventing and Remediating degradation of soils in Europe through Land Care) developed and implemented an innovative participatory stakeholder approach to guide the testing of potential SMMs $[17,18]$ and to identify the factors that hinder their application across Europe. In this work, we: (i) reflect on the experiences from an interdisciplinary stakeholder involvement approach that was conducted in the Veneto region, northeastern Italy, and (ii) examine the opportunities and barriers of this approach with the aim of implementing SMMs to prevent the decline of the SOM.

\section{Materials and Methods}

\subsection{The Veneto Region Case Study, Italy}

Here, the case study was Veneto, a region in northeastern Italy that encompasses an area of about $18,400 \mathrm{~km}^{2}$, of which $55 \%$ is occupied by the Venetian plain. The plain, where most agricultural production is concentrated, is generally flat and rarely exceeds $100 \mathrm{~m}$ above sea level. The plain was formed by the depositional action of the Po and the Adige rivers (southwestern part), Brenta river (middle-northern part) and Piave and Tagliamento rivers (northeastern part). The area surrounding 
the Venice lagoon $\left(1240 \mathrm{~km}^{2}\right.$ ) is even lower (around $2 \mathrm{~m}$ below sea level) and has been cultivated after land reclamation of the 1st century BC. Most of the low-lying plain in Veneto is covered by sandy and silty-clay deposits. According to the World Reference Base classification for the Soil Resources [19], the major soils of the Venetian plain are Calcisols and Cambisols, characterized by a medium natural fertility due to relatively low organic matter (around $15 \mathrm{~g} \mathrm{~kg}^{-1}$ ) and a cation exchange capacity (CEC) from low (in sandy, CEC $=5-10$ meq $100 \mathrm{~g}^{-1}$ ) to high (in silty-clay, CEC $>20$, up to 55 meq $\left.100 \mathrm{~g}^{-1}\right)$. In the last 50 years, SOM has further decreased at rates of $0.02-0.58 \mathrm{Mg} \mathrm{ha}^{-1}$ year $^{-1}[20,21]$ as a consequence of inefficient agricultural practices, which include the conversion from rotations to monocultures (especially maize) and the parallel use of chemical fertilizers over organic amendments. The removal of crop residues for centralized bioenergy production plants raises further concern about the fields in which they are consequently distributed, and the following site-specific potential impact on SOM dynamics. Finally, the persistence of small farms ( $55 \%$ are $<5$ ha, only $5 \%>30$ ha) with low incomes and inadequate generation turnover has hindered the introduction of innovative and efficient agricultural technologies in croplands.

\subsection{Stakeholder Identification and Selection}

Within the RECARE project, the participatory approach consists of different consequential steps [17] that have led to the stakeholders' selection-engagement in identification and valuation of soil management measures (SMMs) - and discussion on existing advantages and constraints around SMMs and soil threats (Figure 1). The early identification of stakeholders around the soil resource was a key step towards a bottom-up, solution-finding approach that aimed to identify SMMs for SOM increase in mineral soils. This was an important part of the process in order to ensure stakeholders who were dealing with soil management were involved and a diversity of stakeholder perspectives were included. According to the methodology proposed by Leventon et al. [22], the identification of stakeholders (Figure 1A) was carried out following consecutive steps. The first step involved the definition of the case study leader's existing network of stakeholders, including himself as a first stakeholder, and the acquisition of basic information on size, organizational structure, area of focus, and policies that stakeholders are aware of. This first step was adopted to evaluate whether existing stakeholder networks covered a wide range of roles, sectors and fields of activity that were relevant to the issue under study. The second step involved the extension of the existing network, which was considered a core sample, by using a snowball sampling methodology. In this phase, previously identified stakeholders were asked to list further stakeholders (approximately six) that they thought should be included in the network. At the same time, information from the lastly identified stakeholders were collected as in the previous stage. Following a snowball sampling process [22], the procedure was repeated from one step to the next, ideally until no new stakeholders were identified. In the final step, case study leaders collected all the stakeholders' information and grouped them according to acquired data.

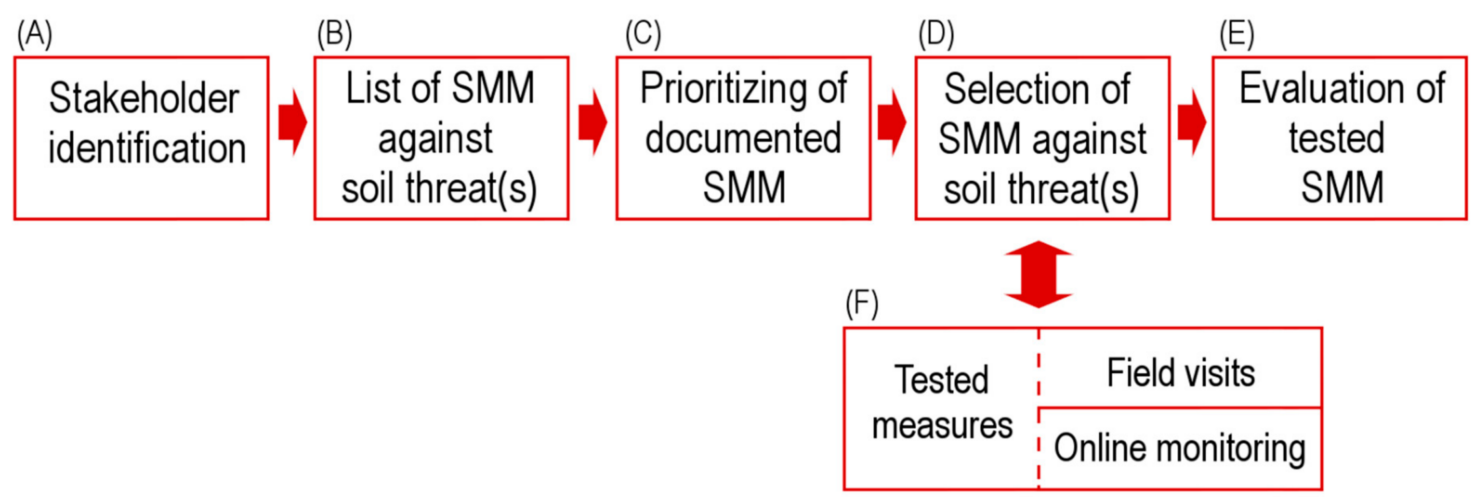

Figure 1. Outline of steps adopted during the participatory approach with stakeholders. 


\subsection{Identification of SMMs with Remediation Options}

Stakeholder involvement through workshops was a cornerstone of the interdisciplinary participatory approach that aimed to identify current and potential SMMs and to select those practices to be tested in the study sites to prevent soil degradation. In fact, with workshops that act as discussion forums, each stakeholder brings his own expertise and knowledge into a shared learning process from one another. The identification of promising (either existing or potentially applicable) measures to prevent SOM depletion was made by stakeholders during a first workshop (Figure 1B). At this workshop, optional measures that were proposed by the case study leader as a result of literature review and his own expertise were integrated with stakeholder's alternatives.

Successively, the World Overview of Conservation Approaches and Technologies (WOCAT) [23,24] was used in the case study (by the case study leader) as a tool to document and monitor SMM alternatives (Figure 1B). This methodology, among others, was adopted to collect information from the fields in the case study with the aim to facilitate comparisons among potentially adopted measures and methodologies [25]. Therefore, questionnaires were filled in with field surveys in case study sites (whether adopted) or from literature reviews (whether only potentially adoptable) to define sustainable agronomic, vegetative, structural and management measures that mitigate soil degradation and enhance the productivity of fields. In addition, the survey included an analysis of socio-economic advantages and disadvantages, as well as the degree of application and acceptance by land users [26].

\subsection{Selection of SMMs with Remediation Options}

During a second meeting, documented practices were presented to stakeholders with the aim to compare possible sustainable SMMs (Figure 1C). A list of environmental, economic and socio-cultural relevant criteria was jointly determined for comparison, according to the basic principles and procedures of evaluation of the area concerned [27]. Criteria were used to prioritize SMMs and finally to select those practices to be tested with field experiments. For this purpose, a methodology including multi-criteria analysis, similar to those proposed by Mendoza et al. [28], was adopted. It was based on the analytic hierarchy process technique [29], i.e., a formal ranking method for obtaining stakeholders' priorities over multiple objectives. This method has been widely applied to, e.g., natural resource management, environmental planning, and watershed-related decision-making [30]. First of all, identified criteria were hierarchically classified in order of importance, based on stakeholder expertise. Secondly for each criterion, a procedure was followed to assign a score to each SMM with the aim to cross information from criteria classification and SMM scoring. Since criteria were classified based on their (preferred by stakeholder) importance, different weights $\left(\mathrm{W}_{\mathrm{c}}\right)$ were assigned and normalized (depending on the number of $\mathrm{n}$ selected criteria) so that their sum was 1 . Per criterion (either environmental, economic or socio-cultural), a score is jointly given by stakeholders to each $\mathrm{SMM}\left(\mathrm{S}_{\mathrm{c}, \mathrm{t}}\right)$, which was weighted by the criteria importance $\left(\mathrm{W}_{\mathrm{c}}\right)$, as previously defined, so that the total SMM practice score $\left(\mathrm{S}_{t}\right)$ was as follows:

$$
\mathrm{S}_{\mathrm{t}}=\sum_{\mathrm{c}=1}^{\mathrm{n}} \mathrm{W}_{\mathrm{c}} \times \mathrm{S}_{\mathrm{c}, \mathrm{t}}
$$

The result was a classification, assuming that a higher score indicated the SMM to choose and to test in the field (Figure 1D). Further details on the adopted multi-criteria analysis have already been extensively reported in $[14,28,31]$.

\subsection{Stakeholder's Perspective of Trialed Measures}

The benefits and drawbacks accrued by field-trialed SMMs were evaluated from different stakeholders' perspectives in a final meeting (Figure 1E). Information on the methodology was widely discussed in Schwilch et al. [32]. Briefly, after identification by the case study leader of measured agroecosystem benefits and drawbacks specifically related to SMMs (e.g., increase/decrease in yields, SOM, water pollution) [33], stakeholders were called to discuss them, eventually to complement 
with qualitative-quantitative effects or to propose changes, and identify the ones most impactful on agroecosystems. The evaluation was done by the stakeholder groups, who scored each benefit or drawback of the trialed measures after a two-year experimentation. Discussion also continued with perspectives of SMM application in a 10-year scenario and a wider area (e.g., valuation at the regional scale).

\subsection{The Field-Trialed Measures and Stakeholder Engagement During the Experiment}

Field experiments that provided data to stakeholders were conducted for 2 years on three farms of the Veneto region [34]. Stakeholders were engaged during the 2-year experiment with a field visit and discussion on the first results from the experiment (Figure 1E). Furthermore, an online platform (https://www.recare-hub.eu/monitoraggio-di-campo-in-real-time) was freely available that reported real-time weather data and soil water dynamics from the experimental fields. Details were provided by Camarotto et al. [34]. This web-based system was adopted with the dual aim of: (i) closing the gap between research experiments and farming activity and (ii) keeping stakeholders engaged during research activity.

\section{Results and Discussion}

\subsection{Stakeholders Selection and Participation}

The sampling process identified a total of 32 stakeholders who were invited to the workshops. Most of the stakeholders were private farmers and farm advisors (18) followed by participants who worked in the public sector and dealt with environmental monitoring, environmental protection, and water management (3); land use policy and planning (1); and agri-environmental research (7). Local and national NGOs involved in education and environmental protection, as well as big companies working in the field of agricultural machinery manufacturers and seed production, were each represented by two stakeholders (Table 1).

Table 1. Number of stakeholders per sector and topic that were identified through the snowball approach in the Veneto region, Italy.

\begin{tabular}{|c|c|c|c|c|c|c|c|}
\hline \multirow[b]{2}{*}{ Topic } & \multicolumn{7}{|c|}{ Sector } \\
\hline & $\begin{array}{c}\text { Public } \\
\text { (Academia) }\end{array}$ & $\begin{array}{c}\text { Public } \\
\text { (Government) }\end{array}$ & $\begin{array}{l}\text { Private } \\
\text { (NGO) }\end{array}$ & $\begin{array}{l}\text { Public } \\
\text { (Other) }\end{array}$ & $\begin{array}{c}\text { Private } \\
\text { (Farmers) }\end{array}$ & $\begin{array}{c}\text { Private (Advisory } \\
\text { Service/Consultants) }\end{array}$ & $\begin{array}{c}\text { Private } \\
\text { (Industry) }\end{array}$ \\
\hline Education & - & - & 1 & - & - & - & - \\
\hline $\begin{array}{l}\text { Environmental } \\
\text { protection and } \\
\text { conservation }\end{array}$ & - & 1 & 1 & - & - & - & - \\
\hline Research & 6 & - & - & 1 & - & - & - \\
\hline Water management & - & - & - & 2 & - & - & - \\
\hline
\end{tabular}

Only twenty stakeholders (60.6\%) attended the first workshop that took place in December 2014, $17(51.5 \%)$ took part in the second workshop (October 2015), and 15 (45.5\%) took place in the third (November 2017) (Table 2). The composition of the stakeholder groups was homogeneous in the different workshops, apart from the people from the NGOs that did not participate in any workshop and those from the industrial sector that did not perceive any benefit from this research after a first approach in the first workshop. 
Table 2. Composition of stakeholder groups during the workshops.

\begin{tabular}{|c|c|c|c|c|c|c|}
\hline $\begin{array}{l}\text { Workshop } \\
\text { Number } \\
\text { (Year) }\end{array}$ & $\begin{array}{l}\text { Main } \\
\text { Activity }\end{array}$ & $\begin{array}{c}\text { Universities, } \\
\text { Public } \\
\text { Authorities, } \\
\text { NGOs }\end{array}$ & $\begin{array}{c}\text { Farm } \\
\text { Advisors }\end{array}$ & Farmers & $\begin{array}{c}\text { Industry } \\
\text { Related to } \\
\text { Agriculture }\end{array}$ & Total \\
\hline $\begin{array}{c}1 \\
(2014)\end{array}$ & $\begin{array}{c}\text { Identification } \\
\text { of promising } \\
\text { SMMs }\end{array}$ & 8 & 6 & 4 & 2 & 20 \\
\hline $\begin{array}{c}2 \\
(2015)\end{array}$ & $\begin{array}{l}\text { Selection of } \\
\text { SMMs to be } \\
\text { tested }\end{array}$ & 9 & 6 & 2 & - & 17 \\
\hline $\begin{array}{c}3 \\
(2017)\end{array}$ & $\begin{array}{c}\text { Valuation of } \\
\text { trialed } \\
\text { SMMs }\end{array}$ & 8 & 3 & 3 & - & 15 \\
\hline
\end{tabular}

\subsection{Identification of SMMs}

Among alternative practices to increase SOM in mineral soils, stakeholders identified four different soil management measures (SMMs), namely: (i) biochar use as soil amendment; (ii) continuous soil cover with cover crops; (iii) conservation agriculture; and (iv) the variable rate application of organic amendments through precision farming techniques (Table 3). Two of the identified SMMs, i.e., conservation agriculture and cover crops, had already been applied in the Veneto region for more than twenty years. Conservation agriculture is a system of agronomic practices that minimizes mechanical soil disturbance, maintains permanent soil cover by using crop residues and cover crops, and rotates crops. Conservation agriculture has been promoted because it provides multiple benefits, such as the mitigation of $\mathrm{CO}_{2}$ emissions and the reduction of energy consumption, the reduction of soil disturbance and of soil erosion. Cover crop practice provides continuous soil cover on croplands, which means that growing seasonal cover crops are alternated with the main crop. Compared with systems that do not use cover crops, continuous soil cover provides long-term agronomic and environmental benefits due to a reduction of negative impacts on agroecosystems, such as the regulation of nutrient cycling and the enhancement of soil structure (Table 3 ). These measures have been recently financed as agri-environmental measures of regional rural development programs [35,36]; however, their application is still negligible $(<1 \%)$ in the Veneto region [37]. During the discussion forum, farmers highlighted that SMM profitability is still very variable, thus making investments and the long-term planning of soil protection strategies unattractive. For instance, the first applications of conservation agriculture were unsuccessful because of improper machinery use, undeveloped technologies, and a lack of technical skills, which negatively affected crop yields. Moreover, a lack of technical solutions (e.g., unsuitable machinery that was too heavy) increased soil degradation (e.g., soil compaction) instead of rehabilitation. This perception had been maintained by stakeholders until now. Regarding cover crops, their effectiveness and use have been hindered by poor knowledge on the timing of intervention, especially when management constraints were related to inaccessible fields (e.g., rainy season and frost/thawing soil) that might delay field operations and compromise main crop yields. These opinions corroborate scientific conclusions on the need to design appropriate packages of farm operations and cultural practices that are specifically designed to implement such systems [38-41] in a local context. 
Table 3. Soil management measures (SMMs) identified by stakeholders in the Veneto region, as well as main characteristics according to World Overview of Conservation

Approaches and Technologies (WOCAT) questionnaires. Additional information is available online in the WOCAT database (https:/qcat.wocat.net/en/wocat/).

\begin{tabular}{|c|c|c|c|c|c|}
\hline SMM & Typology & Main Characteristics & Main Function ${ }^{a}$ & Secondary Functions ${ }^{a}$ & Level of Application \\
\hline $\begin{array}{c}\text { Biochar application as soil } \\
\text { amendment }\end{array}$ & Technology & $\begin{array}{l}\text { Produced from pyrolysis, biochar can } \\
\text { be used as alternative to traditional } \\
\text { amendments (manure, slurry, etc.). }\end{array}$ & $+\mathrm{SOM}$ & $\begin{array}{l}\text { + Nutrient availability (supply, } \\
\text { recycling, etc.) } \\
\text { + Topsoil structure } \\
\text { + Soil water availability } \\
\text { + SOC sequestration }\end{array}$ & Potentially applied \\
\hline Conservation agriculture & Technology & $\begin{array}{l}\text { Management system that includes } \\
\text { no-tillage, permanent soil cover and } \\
\text { crop rotation. }\end{array}$ & - Soil disturbance & $\begin{array}{c}\text { + Control of raindrop splash and } \\
\text { runoff } \\
+ \text { Nutrient cycling } \\
+ \text { Ground cover } \\
+ \text { SOM } \\
+ \text { Water storage } \\
\text { - Energy consumption }\end{array}$ & Existing \\
\hline $\begin{array}{l}\text { Continuous soil cover on } \\
\text { croplands }\end{array}$ & Technology & $\begin{array}{l}\text { Maintenance of continuous soil cover; } \\
\text { succession of mains crops and cover } \\
\text { crops as a practice to improve soil } \\
\text { quality and reduce diffuse } \\
\text { agricultural water pollution. }\end{array}$ & + Ground cover & $\begin{array}{l}\text { + Nutrient cycling } \\
+ \text { SOM } \\
+ \text { Subsoil structure } \\
+ \text { Topsoil structure }\end{array}$ & Existing \\
\hline $\begin{array}{l}\text { Variable rate application } \\
\text { of organic amendments }\end{array}$ & Technology & $\begin{array}{l}\text { Application of precision farming } \\
\text { technologies for the spatial } \\
\text { optimization of organic inputs }\end{array}$ & + SOM stock efficiency & $\begin{array}{l}\text { + Nutrient availability (supply, } \\
\text { recycling, etc.) } \\
\text { + Water quality }\end{array}$ & Potentially applied \\
\hline Carbon farming & $\begin{array}{c}\text { Approach on } \\
\text { management at farm level }\end{array}$ & $\begin{array}{l}\text { Seeks to reduce } \mathrm{CO}_{2} \text { emissions all } \\
\text { along the farm production process, as } \\
\text { well increase yields and carbon } \\
\text { sequestration. }\end{array}$ & $-\mathrm{CO}_{2}$ emissions & $\begin{array}{l}\text { + Integrated carbon management } \\
+ \text { Farm efficiency }\end{array}$ & Potentially applied \\
\hline $\begin{array}{l}\text { Consortium of manure } \\
\text { users and producers }\end{array}$ & $\begin{array}{c}\text { Approach on } \\
\text { management at regional } \\
\text { level }\end{array}$ & $\begin{array}{l}\text { Building a community between } \\
\text { manure producers and users that } \\
\text { encourage manure trading programs, } \\
\text { and offsite and onsite arrangements. }\end{array}$ & + Efficiency of manure use & $\begin{array}{c}\text { + Network of manure producers and } \\
\text { users } \\
+ \text { Improved manure storage, } \\
\text { treatment, etc. }\end{array}$ & Potentially applied \\
\hline
\end{tabular}


Neither the input of biochar-a carbon-enriched by-product of bioenergy production obtained during pyrolysis - as alternative to conventional amendments nor the implementation of precision farming - an automated farming system based on measuring and responding to inter- and intra-field variability-applied to organic input have ever been previously in the Veneto region. When the stakeholder meetings were held, biochar was about to be introduced to the list of soil amendments that are permitted to be used in the Italian agricultural sector, and technical specifications for this product had already been defined [42]. Biochar has been widely studied worldwide in the last decade [43], although interactions between soils and biochar are diverse and still challenging to predict [44]. By adding biochar, basic soil properties (e.g., bulk density, soil water retention, and SOM) are positively affected [45]. However, debate continues on the use of biochar to increase the soil structure [46] because the range of feedstocks and technologies used for its production make it difficult to draw conclusions [47]. In contrast, in precision farming, the variable rate application of fertilizers according to site-specific soil properties is already a feasible and useful technology in terms of automation, data processing, and management [48]. If applied to soil amendment, precision farming might improve nutrient availability and enhance SOM accumulation where actually needed (Table 3). Nevertheless, the combination of manure input with precision farming is still in the initial phase of technological development [49] due to the heterogeneity of organic matrices and the related difficulties of matching field requirements with carbon and nutrients input. These reasons have made the immediate application of the abovementioned technologies by farmers difficult.

Notably, stakeholders also mentioned two approaches that could facilitate measure implementation (e.g., decision-making, technical and material support, and the changing of legal framework and policies). The first one was carbon farming [50], i.e., a holistic approach that includes all the known practices that improve conversion of atmospheric $\mathrm{CO}_{2}$ into plant materials and/or SOM. Second, the creation of a network of manure producers and users was proposed to encourage manure trading programs. In this second scenario, the solution may lie in bringing livestock farms into contact with crop farms that are willing to use manure on their land. For instance, brokerage services or market finder services may be promoted, or market finder websites for manure buyers and sellers may be established, as already suggested by some organizations in the USA (https://lpelc.org/) and cooperatives in China [51]. Despite the interest that emerged regarding these approaches, their effectiveness was not possible to measure in a two-year field experiment, so they were removed from the selection.

\subsection{Prioritizing and Selection of $S M M$ s}

During a second workshop, stakeholders were asked to choose SMMs to test in the field. More than $50 \%$ of the total weight was assigned to five out of the 12 criteria belonging to the economic, environmental and socio-cultural categories (Table 4). Participants ranked "reduced/low costs of application" $\left(\mathrm{W}_{\mathrm{c}}=0.143\right)$ as the most relevant economic sub-criterion to evaluate SMMs, followed by the environmental sub-criterion "improved soil physical fertility" $\left(\mathrm{W}_{\mathrm{c}}=0.125\right)$. "Increased farmer awareness" and "improved landscape quality" (socio-cultural criteria), as well as "reduced management for crop protection" (economic), had scores of 0.089. In total, five criteria were grouped into both environmental and economic categories, whereas two of them were grouped as socio-cultural. 
Table 4. Ranking of selected criteria by stakeholders in the Veneto region, Italy.

\begin{tabular}{ccc}
\hline Criteria & Sub-criteria & $\mathbf{W}_{\mathbf{c}}{ }^{\mathbf{a}}$ \\
\hline Economic & Reduced/low costs of application & 0.143 \\
Environmental & Improved soil fertility & 0.125 \\
Socio-cultural & Increased farmer awareness & 0.089 \\
Socio-cultural & Improved landscape quality & 0.089 \\
Economic & Reduced management for crop protection & 0.089 \\
Environmental & Reduced greenhouse gas emissions & 0.071 \\
Economic & Reduced bureaucratic and administrative costs & 0.071 \\
Economic & Reduced fertilizers input & 0.071 \\
Environmental & Improved water quality & 0.071 \\
Environmental & Improved ecosystem functions & 0.071 \\
Economic & Improved market opportunities & 0.054 \\
Environmental & Increased soil biodiversity & 0.054 \\
\hline
\end{tabular}

a Normalized weights.

The scoring results of each SMM according to multi-criteria analysis [28] revealed that the benefits of biochar input were mainly associated with a reduction in greenhouse gas emissions and improved soil fertility (Figure 2). Socio-cultural aspects regarding biochar input were the least valued among the criteria for SMMs (Figure 2).

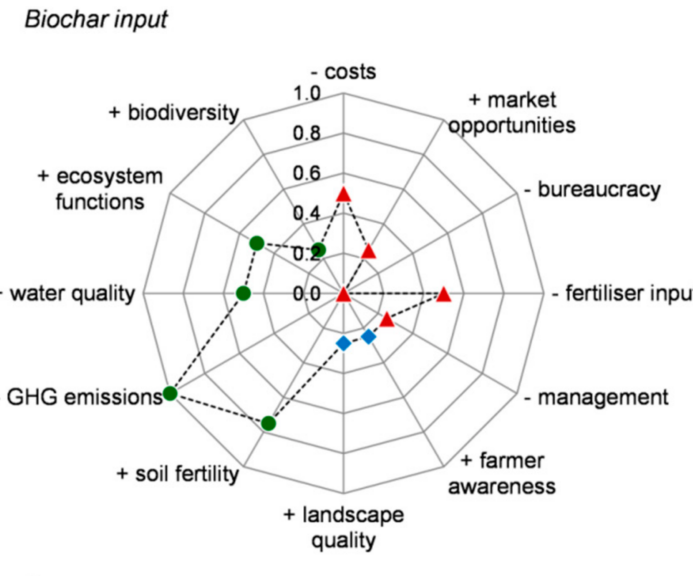

Conservation agriculture

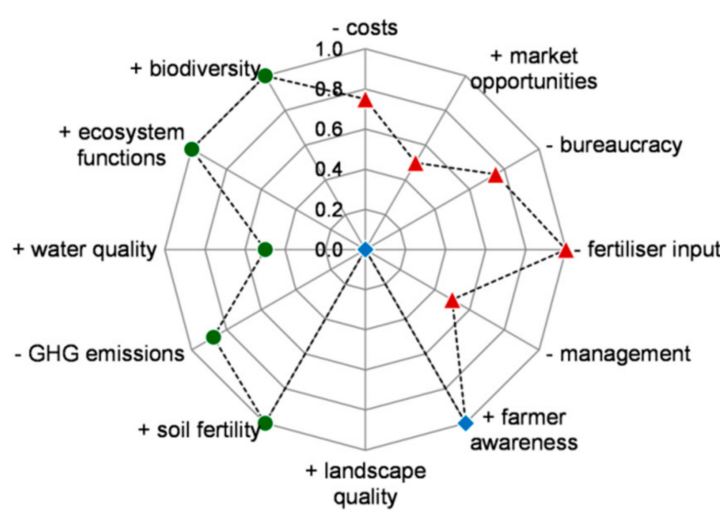

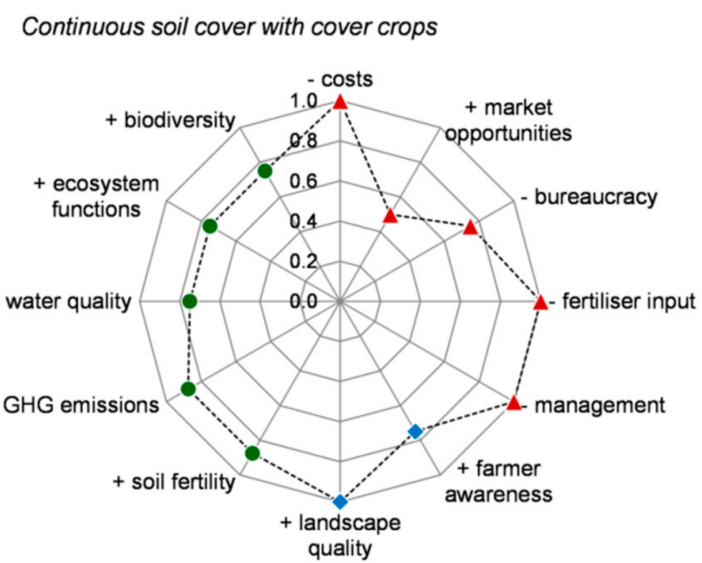

Variable rate manure application

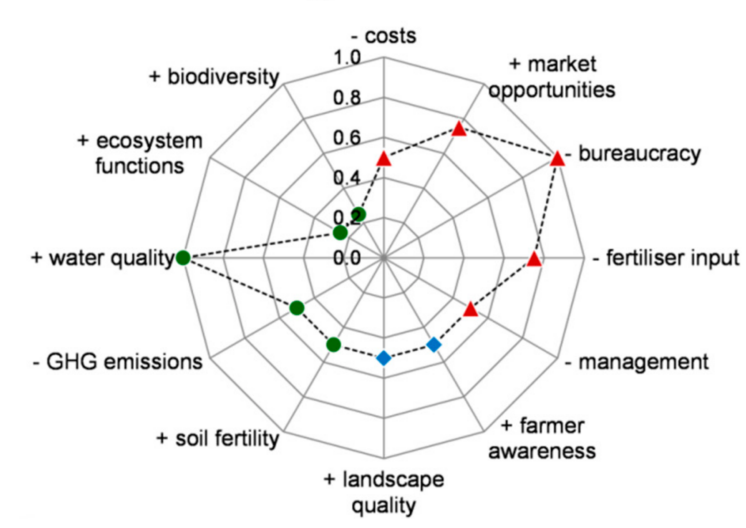

Figure 2. Normalized scoring results of SMMs for the different criteria (economic are red triangles, environmental are green circles, and socio-cultural are blue diamonds) that have been selected in the Veneto region, Italy. Note: Symbols "+" and "-" mean respectively "increase of" and "decrease of".

As highlighted in the participatory discussion with stakeholders, biochar was a relatively unfamiliar innovation technology, and this unfamiliarty has likely affected its perception from a 
socio-cultural perspective. A recent paper by Latawiec et al. [52] reported similar results about biochar use by farmers, as people's resistance to new approaches and technologies was often driven by their confidence in the information, knowledge, and familiarity of them [53], thus going beyond the economic and technological aspects [54]. Continuous soil cover with cover crops yielded a major impact in the highly ranked economic criterion, i.e., "reduced/low costs of application," as well as in "reduced fertilizer input." Stakeholders valued that the adoption of cover crops did not contribute to increase investments and management costs while allowing them to significantly improve nutrient cycling. Notably, the highest score was also given to the improvement of landscape quality, suggesting that cover crops could be perceived in the local context as similar to meadows and offset the negative visual impact of bare soil as a human intervention [55]. Surprisingly, although conservation agriculture was also characterized by cover crops, the improvement of landscape quality was not positively valued by stakeholders. Conservation agriculture in the Veneto region included no-tillage, which meant poor weed control and, in turn, the presence of unmanaged fields for the stakeholders involved in the farm management. This aspect would more negatively impact the landscape quality than regularly ploughed soils [56]. In contrast, conservation agriculture yielded high scores in other environmental, economic and socio-cultural aspects, such as the improvement of soil fertility and soil biodiversity (i.e., the variation in soil life, from genes to communities), the reduction of costs for field operations, and the augmented awareness on farmers towards soil conservation measures (Figure 2). Finally, the variable rate manure application did not convince the stakeholders for several aspects, because it was perceived as an expensive practice whose management is still complex for a farmer. Moreover, improvements in terms of soil biodiversity, ecosystem functions (i.e., the capacity of natural processes and components to provide goods and services that satisfy human needs), and soil fertility were not highlighted, most likely because very few real-world examples of their applicability were reported. Only the improvement of water quality-due to the nitrogen $(\mathrm{N})$ input reduction because of higher $\mathrm{N}$ efficiency-was perceived as having a positive impact, because it could improve the compliance to environmental regulatory constraints (e.g., Nitrates Directive and Water Framework Directive) and potentially reduce bureaucratic costs for farmers (e.g., proving the effectiveness of the agricultural practices). According to scoring results, continuous cover crops on soils and conservation agriculture were finally selected as the most promising measures to be tested in the field (Figure 3). In contrast, the most innovative practices, such as using biochar, were discarded as being too advanced and unknown to be proposed for farming activity.

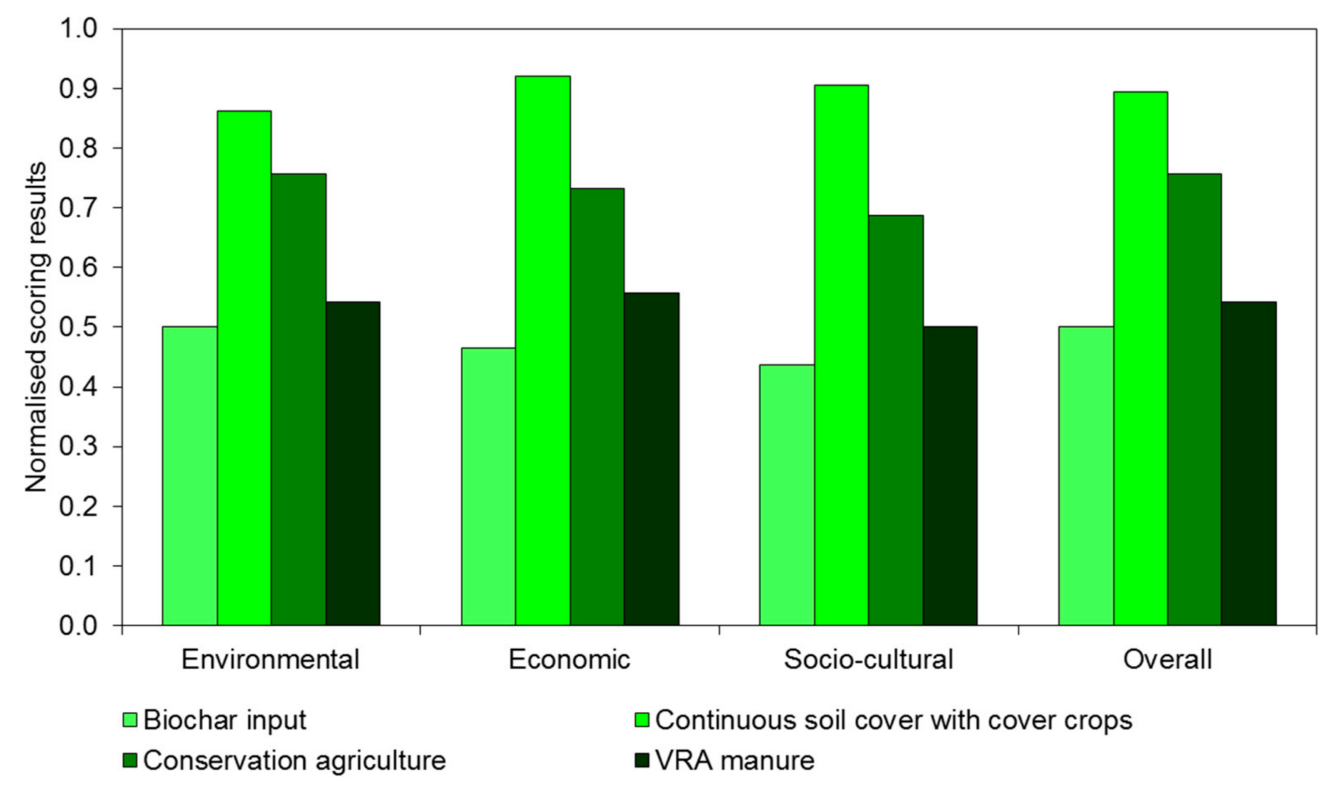

Figure 3. Overall scoring of identified SMM practices in the different categories in the Veneto region, Italy. 


\subsection{Evidence of how Measures Worked out and Perception of Stakeholders}

A change of soil management affects the ecosystem services that people derive from land. In this context, the aim of the last workshop with stakeholders was to evaluate benefits and drawbacks as provided by the trialed measures, i.e., continuous soil cover with cover crops and conservation agriculture [34]. Stakeholders agreed that the main short-term benefit of using cover crops was the improvement of water quality (both surface water and groundwater; $33.3 \%$ of votes), as supported by the experimental results of the trialed measure (Table 5). Notably, continuous education ranked second, getting a higher score (0.26) compared to weed control (0.097). In fact, discussions between participants highlighted that the implementation of new technologies/techniques involves management adaptations and novelties in the approach of the farming system, placing stakeholders (especially farmers) on a self-sustained education path. An increase in soil fertility was only mentioned by stakeholders as a long-term outcome. In fact, trialed measures in real-world conditions led to the same results, i.e., the cover crops did not affect the main soil fertility indicators ( $\mathrm{N}$ and SOM content) in the short term; they only did so in long-term simulations [34]. This aspect highlighted that linking action (i.e., experiments) to knowledge during the participatory process is pivotal to enhance the credibility of produced data and, in turn, improve the stakeholders understanding of trialed measures [57]. Drawbacks corroborated initial discussions during the first workshop (in 2014) about field management constraints, such as the timing of planting or green manure incorporation, although they can be overcome in the long term according to stakeholders' perceptions. Finally, a change in the hydrological cycle could be a benefit (e.g., enhanced water holding capacity and reduced runoff) for some stakeholders or be a drawback (e.g., reduced available water for the main crops) for others (Table 5). 
Table 5. Valuation (0-1 range) of benefits and drawbacks provided by stakeholders on trialed SMMs in the short-term and on a regional long-term application.

\begin{tabular}{|c|c|c|c|c|c|c|c|c|}
\hline \multirow{2}{*}{$\begin{array}{l}\text { Continuous Soil Cover with Cover Crops } \\
\text { Benefits }\end{array}$} & \multicolumn{2}{|c|}{ Universities, Public Authorities, NGOs } & \multicolumn{2}{|c|}{ Farm Advisors } & \multicolumn{2}{|c|}{ Farmers } & \multicolumn{2}{|c|}{ Total } \\
\hline & Short-Term, Local & $\begin{array}{l}\text { Long-Term, } \\
\text { Regional }\end{array}$ & $\begin{array}{l}\text { Short-Term, } \\
\text { Local }\end{array}$ & $\begin{array}{c}\text { Long-Term, } \\
\text { Regional }\end{array}$ & $\begin{array}{l}\text { Short-Term, } \\
\text { Local }\end{array}$ & $\begin{array}{l}\text { Long-Term, } \\
\text { Regional }\end{array}$ & $\begin{array}{c}\text { Short-Term, } \\
\text { Local }\end{array}$ & $\begin{array}{c}\text { Long-Term, } \\
\text { Regional }\end{array}$ \\
\hline Improvement of surface water quality & 13.5 & 13.9 & 21.5 & 41.2 & 9.9 & 17.7 & 13.9 & 21.4 \\
\hline Improvement of groundwater quality & 21.6 & 30.6 & 21.5 & 11.7 & 15.0 & 23.5 & 19.4 & 24.3 \\
\hline Weed control & 5.4 & - & 7.1 & - & 15.0 & - & 9.7 & - \\
\hline Continuous learning & 27.0 & 16.7 & 28.5 & 23.5 & 25.0 & 35.4 & 26.4 & 22.9 \\
\hline $\begin{array}{l}\text { Increase soil fertility } \\
\text { Drawbacks }\end{array}$ & - & 19.4 & - & 17.7 & - & 11.7 & - & 17.1 \\
\hline $\begin{array}{l}\text { Field management constraints } \\
\text { Benefits and/or drawbacks }\end{array}$ & 10.8 & - & 0.0 & - & 20.0 & - & 11.1 & - \\
\hline Change in water cycle ${ }^{a}$ & 21.6 & 19.4 & 21.5 & 5.8 & 15.0 & 11.7 & 19.4 & 14.0 \\
\hline \multicolumn{9}{|l|}{$\begin{array}{c}\text { Conservation agriculture } \\
\text { Benefits }\end{array}$} \\
\hline $\begin{array}{l}\text { Improvement of organic carbon stabilization } \\
\qquad(\mathrm{C} / \mathrm{N} \text { ratio })\end{array}$ & 4.5 & 26.3 & 3.1 & 10.0 & 10.0 & 23.8 & 5.5 & 21.5 \\
\hline Reduction of GHGs emissions & 18.2 & - & 12.5 & - & 23.4 & - & 18.0 & - \\
\hline Increase of soil biodiversity & 19.7 & - & 9.4 & - & 3.3 & - & 13.3 & - \\
\hline Continuous education & 15.2 & 15.8 & 12.5 & 20.1 & 16.6 & 28.7 & 14.8 & 20.3 \\
\hline $\begin{array}{l}\text { Simplification of soil management due to } \\
\text { technical improvement }\end{array}$ & - & 7.9 & - & 10.0 & - & 9.5 & - & 8.9 \\
\hline Stabilization of crop production & - & 10.5 & - & 20.1 & - & 14.3 & - & 13.9 \\
\hline $\begin{array}{c}\text { Increase of soil carbon sequestration } \\
\text { Drawbacks }\end{array}$ & - & 10.5 & - & 10.0 & - & 9.5 & - & 10.1 \\
\hline Decreased crop yield & 10.6 & - & 18.8 & - & 16.6 & - & 14.1 & - \\
\hline Potential soil compaction & 13.6 & - & 3.1 & & 3.3 & - & 8.6 & - \\
\hline Machinery-initial investment & 3.0 & - & 12.5 & & 3.3 & - & 5.5 & - \\
\hline High expertise and knowledge required & 3.0 & - & 18.8 & & 13.3 & - & 9.4 & - \\
\hline $\begin{array}{l}\text { Low capacity to maintain the SLM system in } \\
\text { the long-term }\end{array}$ & - & 5.3 & - & 5.0 & - & - & - & 3.8 \\
\hline $\begin{array}{c}\text { Increase in pesticide use } \\
\text { Benefits and/or drawbacks }\end{array}$ & - & 5.3 & - & 20.1 & - & 4.7 & - & 8.9 \\
\hline Change in water cycle ${ }^{a}$ & 12.1 & 18.4 & 9.4 & 5.0 & 10.0 & 9.5 & 10.9 & 12.7 \\
\hline
\end{tabular}

a Contrasting results do not make it neither positive nor negative. 
Contrary to perception about cover crops, at the basis of stakeholder valuation was the understanding that conservation agriculture could produce benefits that were strictly related to the increase of SOM in the mineral soils. In particular, the improvement of organic carbon stabilization (increase of the $\mathrm{C} / \mathrm{N}$ index) and the long-term increase in carbon sequestration were reported. Stakeholders also mentioned a reduction in GHGs as an immediate effect of reduced tillage operations and reduced energy use. Notably, stakeholders' perceptions were that motivations for not adopting conservation agriculture in the short term were not just economic (e.g., a decrease in crop yields and high initial investments for machinery that reduce immediate profitability), as they were also environmental (e.g., potential soil compaction) and socio-cultural (e.g., high expertise and knowledge required). Nevertheless, they were mostly converted into potential benefits in a long term scenario (Table 5), suggesting that improvements were required and possible according to the participants' perspectives. Finally, doubts arose about the increase in pesticide use with conservation agriculture that in the Veneto region was financially supported only under no-tillage [35], thus capping any tillage operation for weed control.

\subsection{Outcomes from Stakeholders Participatory Approach}

The snowball sampling methodology was able to reach and identify a broad range of stakeholders around the problem of land degradation and rehabilitation, as already observed by Leventon et al. [22]. Each of the identified groups had inherently different forms of knowledge and roles in relation to the agricultural sector and SOM, giving the research a broad range of ideas and opinions for SOM depletion solutions. Moreover, it has been argued that agri-environmental management is more effective when the collaboration instead of fragmentation of different actors is promoted [58], which might help to (i) overcome conventional approaches where each typology of stakeholder mainly considers the advantages of its own activity [59], (ii) promote the application of SMMs to farmers by examining a wide array of factors that are not all directly economic [60], and (iii) anticipate the lagged effect on the awareness of specific threats by some stakeholders such as SOM depletion [11]. However, only half of the stakeholders (on average) that were initially identified participated to the organized meetings. It was likely that some stakeholders perceived the idea of getting involved in decision-making only at the advanced stage of implementation phase of the project, and not in earlier project identification and preparation phases. Therefore, stakeholders may have felt involved in a project that is at oods with their own needs and priorities [61]. Anyway, stakeholders who participated were mostly representative of their constituents (e.g., members of trade associations) and capable of looking after collective interests as well as those of their own group, as also reported in previous studies [62]. The participatory approach has influenced research such that the stakeholders controlled the priority settings [63] by choosing to test SMMs in advanced adaptive stages (i.e., cover crops and conservation agriculture) rather than those aimed to cover knowledge gaps (biochar input) or early adaptive stages (variable rate manure application), as already observed in other studies [64]. In fact, the participatory approach highlighted the stakeholders' needs to translate expectations from research outcomes into practice $[65,66]$ and to validate robust research results with technology effectiveness and applicability in real-world demonstrations [57]. According to Magrini et al. [67], the stakeholders' selection of technologies was based on the need for their improvement by strengthening the technological trajectory that has been already adopted in the local context of the Veneto region. In fact, it is likely that multiple dependencies between technical (e.g., machinery manufacturers and farmers' skills,) and social components (e.g., an increased awareness of public and policy makers, as well as an improvement of knowledge transfer) of the agricultural system were reinforced over time, leading to a preference of already started technologies instead of new ones. It is also likely that routines and standards within which stakeholders operated might have hindered their creative capacity for innovative solutions. Recent results by Ingram et al. [68] emphasized our hypothesis: The authors suggested a tendency to restrict their issues to known themes for some stakeholders, thus limiting the opportunity for advancing innovation and restricting the scope of new solutions. Even Sumberg et al. [69], in reviewing practitioner involvement in the field of new 
product development, found that "typical farmers" identified more likely topics they were familiar with, while "research-minded farmers" were more enquiring in their issue identification and, arguably, their evaluation of solutions. Thirdly, the uncertainty surrounding alternative solutions could reinforce the choices that are closer to conventional practices. In this context, the participatory approach highlighted some constraints researchers could face, such as the risk of compromising scientific freedom, neutrality in the definition of research agendas, or accumulation of knowledge for its own sake [70]. In fact, some authors (e.g., [71]) have emphasized that limits of scientific understanding of the system (in our case, agroecosystem) complexity by users might limit innovative or exploratory research, such that researchers' desire to test complex and innovative solutions falls short of stakeholders' needs.

The results of the evaluation of trialed measures emphasized that stakeholders' perspectives about soil are broader than just productivity and profitability. This also relates to how land managers and society value and connect to the soil, the connectivity dimension as hypothesized by McBratney et al. [72]. Increased connectivity could bring a social dimension to soil, where participatory and facilitatory approaches are driven by the understanding that soil cannot be viewed only from a productivist viewpoint-it must also be valued as stock for other services. Nevertheless, it is difficult to disentangle whether the participatory approach has changed stakeholders' perceptions of the soil resource or whether personal motivation was the main driver towards the perception of soil functions. For instance, recent studies [73] have highlighted that stakeholders, especially farmers, may adopt pro-environmental measures for non-environmental reasons, e.g., pursuing production improvements with innovative soil management measures (e.g., the use of cover crops) or seeking personal or family health and well-being (e.g., reduced use of pesticides).

\section{Conclusions}

The adoption of sustainable soil management measures (SMMs) to mitigate SOM decline was found to be related to stakeholders' perceptions of economic, environmental and socio-cultural factors, as well as the stakeholders' understanding of their effectiveness. By adopting a bottom-up participatory approach, stakeholders focused on implementing SMMs that were already known to farmers (i.e., continuous soil cover with cover crops and conservation agriculture) as alternatives to conventional practices to increase SOM, thus hindering the research of innovative solutions. This confidence with technologies, and even with their drawbacks, were the reasons why stakeholders intended to test SMMs in advanced stages in field experiments. Stakeholders were relatively unfamiliar with the most innovative technologies, whose perception was of uncertainty in their effectiveness and difficulties in the implementation. However, the approach was promising because it increased co-learning between researchers and farmers, experiential learning, and resulted in factors other than productivity and profitability being considered. Regardless of the stage of innovation, this study highlighted that the transition from conventional to sustainable agricultural practices requires the legitimation of SMMs and the credibility of produced data, an increased awareness on SOM depletion, and improved bottom-up stakeholder engagement with community empowerment in the decision process.

Author Contributions: Conceptualization, N.D.F. and F.M.; methodology, N.D.F., C.C. and F.M.; formal analysis, N.D.F. and C.C.; investigation, N.D.F., C.C., I.P., A.B., J.M. and F.M.; data curation, N.D.F., C.C. and F.M.; writing-original draft preparation, N.D.F.; writing-review and editing, N.D.F., C.C., I.P., A.B., J.M. and F.M; supervision, F.M.; project administration, F.M.; funding acquisition, F.M. All authors have read and agreed to the published version of the manuscript.

Funding: The research leading to these results has received funding from the European Union Seventh Framework Programme (FP7/2007-2013) under grant agreement No. 603498 (RECARE project).

Acknowledgments: The authors would also like to thank all stakeholders that participated to the activities and contributed to valuable discussions.

Conflicts of Interest: The authors declare no conflict of interest. 


\section{References}

1. Lal, R. Managing soils and ecosystems for mitigating anthropogenic carbon emissions and advancing global food security. Bioscience 2010, 60, 708-721. [CrossRef]

2. Jones, A.; Panagos, P.; Barcelo, S.; Bouraoui, F.; Bosco, C.; Dewitte, O.; Gardi, C.; Erhard, M.; Hervas, J.; Hiederer, R.; et al. The State of Soil in Europe; Publications Office of the European Union: Luxemburg, 2012.

3. Lal, R. Digging Deeper: A Holistic Perspective of Factors Affecting Soil Organic Carbon Sequestration in Agroecosystems. Glob. Chang. Biol. 2018, 24, 3285-3301. [CrossRef]

4. Morari, F.; Berti, A.; Dal Ferro, N.; Piccoli, I. Deep Carbon sequestration in cropping systems. In Sustainable Agriculture Reviews 29; Lal, R., Francaviglia, R., Eds.; Springer: Cham, Switzerland, 2019; pp. 33-65.

5. Smith, P.; House, J.I.; Bustamante, M.; Sobocká, J.; Harper, R.; Pan, G.; West, P.C.; Clark, J.M.; Adhya, T.; Rumpel, C.; et al. Global change pressures on soils from land use and management. Glob. Chang. Biol. 2016, 22, 1008-1028. [CrossRef]

6. Caspari, T.; van Lynden, G.; Bai, Z. Land Degradation Neutrality: An Evaluation of Methods; Umweltbundesamt: Dessau-Roßlau, Germany, 2015; Available online: https://www.umweltbundesamt.de/sites/default/files/ medien/378/publikationen/texte_62_2015_land_degradation_neutrality_0.pdf (accessed on 30 December 2019).

7. Minelli, S.; Erlewein, A.; Castillo, V. Land Degradation Neutrality and the UNCCD: From Political Vision to Measurable Targets. In International Yearbook of Soil Law and Policy 2016; Springer: Cham, Switzerland, 2017; pp. 85-104.

8. Louwagie, G.; Gay, S.H.; Burrell, A. Addressing Soil Degradation in EU Agriculture: Relevant Processes, Practices and Policies; European Commission: Brussels, Belgium, 2009.

9. Friedrich, T.; Kassam, A.; Corsi, S. Conservation agriculture in Europe. In Conservation Agriculture: Global Prospects and Challenge; Jat, R.A., Sahrawat, K.L., Kassam, A.H., Eds.; CABI: Wallingford, UK, 2014; pp. 127-179.

10. Prager, K. Agri-environmental collaboratives for landscape management in Europe. Curr. Opin. Environ. Sustain. 2015, 12, 59-66. [CrossRef]

11. Hijbeek, R.; Cormont, A.; Hazeu, G.; Bechini, L.; Zavattaro, L.; Janssen, B.; Werner, M.; Schlatter, N.; Guzmán, G.; Bijttebier, J.; et al. Do farmers perceive a deficiency of soil organic matter? A European and farm level analysis. Ecol. Indic. 2017, 83, 390-403. [CrossRef]

12. Schneider, F.; Fry, P.; Ledermann, T.; Rist, S. Social learning processes in Swiss soil protection-The "From farmer-to farmer" project. Hum. Ecol. 2009, 37, 475-489. [CrossRef]

13. Illukpitiya, P.; Gopalakrishnan, C. Decision-making in soil conservation: Application of a behavioral model to potato farmers in Sri Lanka. Land Use Policy 2004, 21, 321-331. [CrossRef]

14. Panagea, I.S.; Daliakopoulos, I.N.; Tsanis, I.K.; Schwilch, G. Evaluation of promising technologies for soil salinity amelioration in Timpaki (Crete): A participatory approach. Solid Earth 2016, 7, 177-190. [CrossRef]

15. Görg, C. Landscape governance: The "politics of scale" and the "natural" conditions of places. Geoforum 2007, 38, 954-966. [CrossRef]

16. Enengel, B.; Penker, M.; Muhar, A. Landscape co-management in Austria: The stakeholder's perspective on efforts, benefits and risks. J. Rural Stud. 2014, 34, 223-234. [CrossRef]

17. Keizer, J.J.; Hessel, R. Quantifying the effectiveness of stakeholder-selected measures against individual and combined soil threats. Catena 2019, 182, 104148. [CrossRef]

18. Okpara, U.T.; Fleskens, L.; Stringer, L.C.; Hessel, R.; Bachmann, F.; Daliakopoulos, I.; Berglund, K.; Velazquez, F.J.B.; Ferro, N.D.; Keizer, J.; et al. Helping stakeholders select and apply appraisal tools to mitigate soil threats: Researchers' experiences from across Europe. J. Environ. Manag. 2020, 257, 110005. [CrossRef]

19. FAO. World Reference Base for Soil Resources 2014. International Soil Classification System for Naming Soils and Creating Legends for Soil Maps; FAO: Rome, Italy, 2014.

20. Berti, A.; Morari, F.; Dal Ferro, N.; Simonetti, G.; Polese, R. Organic input quality is more important than its quantity: C turnover coefficients in different cropping systems. Eur. J. Agron. 2016, 77, 138-145. [CrossRef]

21. Morari, F.; Lugato, E.; Berti, A.; Giardini, L. Long-term effects of recommended management practices on soil carbon changes and sequestration in north-eastern Italy. Soil Use Manag. 2006, 22, 71-81. [CrossRef]

22. Leventon, J.; Fleskens, L.; Claringbould, H.; Schwilch, G.; Hessel, R. An applied methodology for stakeholder identification in transdisciplinary research. Sustain. Sci. 2016, 11, 763-775. [CrossRef] [PubMed] 
23. Liniger, H.; Schwilch, G. Enhanced decision-making based on local knowledge: The WOCAT method of sustainable soil and water management. Moutain Res. Dev. 2002, 22, 14-18. [CrossRef]

24. Schwilch, G.; Bestelmeyer, B.; Bunning, S.; Critchley, W.; Herrick, J.; Kellner, K.; Liniger, H.P.; Nachtergaele, F.; Ritsema, C.J.; Schuster, B.; et al. Experiences in monitoring and assessment of sustainable land management. Land Degrad. Dev. 2011, 22, 214-225. [CrossRef]

25. Liniger, H.; Cahill, D.; Thomas, D.B.; van Lynden, G.W.J.; Schwilch, G. Categorization of SWC technologies and approaches: A global need? In Proceedings of the ISCO Conference 2002, Beijing, China, 26-31 May 2002; Volume 3, pp. 6-12. Available online: http://www.tucson.ars.ag.gov/isco/isco12/VolumeIII/ CategorizationofSWCTechnologies.pdf (accessed on 30 December 2019).

26. Schwilch, G.; Bachmann, F.; Liniger, H. Appraising and selecting conservation measures to mitigate desertification and land degradation based on stakeholder participation and global best practices. Land Degrad. Dev. 2009, 20, 308-326. [CrossRef]

27. Rossiter, D.G. Lecture Notes: Land Evaluation; College of Agriculture \& Life Sciences, Cornell University: Ithaca, NY, USA, 1994; Available online: http://www.css.cornell.edu/faculty/dgr2/Docs/Scas494/s494ch1.pdf (accessed on 30 December 2019).

28. Mendoza, G.A.; Macoun, P.; Prabhu, R.; Sukadri, D.; Purnomo, H.; Hartanto, H. Guidelines for Applying Multi-Criteria Analysis to the Assessment of Criteria and Indicators; Center for International Forestry Research (CIFOR): Jakarta, Indonesia, 2000.

29. Saaty, T.L. Decision Making for Leaders: The Analytic Hierarchy Process for Decisions in a Complex World; RWS Publications: Pittsburgh, PA, USA, 1995.

30. Dos Santos, P.H.; Neves, S.M.; Sant'Anna, D.O.; de Oliveira, C.H.; Carvalho, H.D. The analytic hierarchy process supporting decision making for sustainable development: An overview of applications. J. Clean. Prod. 2019, 212, 119-138. [CrossRef]

31. Scholten, L.; Schuwirth, N.; Reichert, P.; Lienert, J. Tackling uncertainty in multi-criteria decision analysis-An application to water supply infrastructure planning. Eur. J. Oper. Res. 2015, 242, 243-260. [CrossRef]

32. Schwilch, G.; Lemann, T.; Berglund, Ö.; Camarotto, C.; Cerdà, A.; Daliakopoulos, I.; Kohnová, S.; Krzeminska, D.; Marañón, T.; Rietra, R.; et al. Assessing Impacts of Soil Management Measures on Ecosystem Services. Sustainability 2018, 10, 4416. [CrossRef]

33. Haines-Young, R.; Potschin, M. Common International Classification of Ecosystem Services (CICES): Consultation on Version 4, August-December 2012. EEA Framework Contract No EEA/IEA/09/003; Centre for Environmental Management, School of Geography, University of Nottingham: Nottingham, UK, 2013; Available online: https://cices.eu/ (accessed on 30 December 2019).

34. Camarotto, C.; Dal Ferro, N.; Piccoli, I.; Polese, R.; Furlan, L.; Chiarini, F.; Morari, F. Conservation agriculture and cover crop practices to regulate water, carbon and nitrogen cycles in the low-lying Venetian plain. Catena 2018, 167, 236-249. [CrossRef]

35. Regione del Veneto. Programma di Sviluppo Rurale del Veneto 2007-2013. Available online: https: //www.regione.veneto.it/web/agricoltura-e-foreste/psr-2007-2013 (accessed on 30 December 2019).

36. Regione del Veneto. Programma di Sviluppo Rurale del Veneto 2014-2020. Available online: https: //www.regione.veneto.it/web/agricoltura-e-foreste/sviluppo-rurale-2020 (accessed on 30 December 2019).

37. Dal Ferro, N.; Cocco, E.; Lazzaro, B.; Berti, A.; Morari, F. Assessing the role of agri-environmental measures to enhance the environment in the Veneto Region, Italy, with a model-based approach. Agric. Ecosyst. Environ. 2016, 232, 312-325. [CrossRef]

38. Bergtold, J.S.; Ramsey, S.; Maddy, L.; Williams, J.R. A review of economic considerations for cover crops as a conservation practice. Renew. Agric. Food Syst. 2017, 34, 62-76. [CrossRef]

39. Dunn, M.; Ulrich-Schad, J.D.; Prokopy, L.S.; Myers, R.L.; Watts, C.R.; Scanlon, K. Perceptions and use of cover crops among early adopters: Findings from a national survey. J. Soil Water Conserv. 2016, 71, 29-40. [CrossRef]

40. Giller, K.E.; Andersson, J.A.; Corbeels, M.; Kirkegaard, J.; Mortensen, D.; Erenstein, O.; Vanlauwe, B. Beyond conservation agriculture. Front. Plant Sci. 2015, 6, 870. [CrossRef]

41. Lal, R. Sequestering carbon and increasing productivity by conservation agriculture. J. Soil Water Conserv. 2015, 70, 55A-62A. [CrossRef] 
42. Meyer, S.; Genesio, L.; Vogel, I.; Schmidt, H.-P.; Soja, G.; Someus, E.; Shackley, S.; Verheijen, F.G.A.; Glaser, B. Biochar standardization and legislation harmonization. J. Environ. Eng. Landsc. Manag. 2017, 25, 175-191. [CrossRef]

43. Kavitha, B.; Reddy, P.V.L.; Kim, B.; Lee, S.S.; Pandey, S.K.; Kim, K.-H. Benefits and limitations of biochar amendment in agricultural soils: A review. J. Environ. Manage. 2018, 227, 146-154. [CrossRef]

44. Lorenz, K.; Lal, R. Biochar. In Carbon Sequestration in Agricultural Ecosystems; Springer International Publishing: Cham, Switzerland, 2018; pp. 301-355.

45. Ali, S.; Rizwan, M.; Qayyum, M.F.; Ok, Y.S.; Ibrahim, M.; Riaz, M.; Arif, M.S.; Hafeez, F.; Al-Wabel, M.I.; Shahzad, A.N. Biochar soil amendment on alleviation of drought and salt stress in plants: A critical review. Environ. Sci. Pollut. Res. 2017, 24, 12700-12712. [CrossRef]

46. Pituello, C.; Dal Ferro, N.; Francioso, O.; Simonetti, G.; Berti, A.; Piccoli, I.; Pisi, A.; Morari, F. Effects of biochar on the dynamics of aggregate stability in clay and sandy loam soils. Eur. J. Soil Sci. 2018, 69, 827-842. [CrossRef]

47. Blanco-Canqui, H. Biochar and Soil Physical Properties. Soil Sci. Soc. Am. J. 2017, 81, 687. [CrossRef]

48. Bruce, M.A.; Moretto, J.; Polese, R.; Morari, F. Optimizing durum wheat cultivation in Northern Italy: Assessing proximal and remote sensing derived from different platforms for variable-rate application of nitrogen. In Precision Agriculture '19; Wageningen Academic Publishers: Wageningen, The Netherlands, 2019; pp. 23-28.

49. Moshia, M.E.; Khosla, R.; Davis, J.G.; Westfall, D.G.; Doesken, K. Precision Manure Management on Site-Specific Management Zones: Topsoil Quality and Environmental Impact. Commun. Soil Sci. Plant Anal. 2015, 46, 235-258. [CrossRef]

50. Toensmeier, E. The Carbon Farming Solution: A Global Toolkit of Perennial Crops and Regenerative Agriculture Practices for Climate Change Mitigation and Food Security; Chelsea Green Publishing: White River Junction, VT, USA, 2016.

51. Bluemling, B.; Wang, F. An institutional approach to manure recycling: Conduit brokerage in Sichuan Province, China. Resour. Conserv. Recycl. 2018, 139, 396-406. [CrossRef]

52. Latawiec, A.; Królczyk, J.; Kuboń, M.; Szwedziak, K.; Drosik, A.; Polańczyk, E.; Grotkiewicz, K.; Strassburg, B. Willingness to Adopt Biochar in Agriculture: The Producer's Perspective. Sustainability 2017, 9, 655. [CrossRef]

53. Thompson, J.; Scoones, I. Addressing the dynamics of agri-food systems: An emerging agenda for social science research. Environ. Sci. Policy 2009, 12, 386-397. [CrossRef]

54. Vanclay, F. Social principles for agricultural extension to assist in the promotion of natural resource management. Aust. J. Exp. Agric. 2004, 44, 213-222. [CrossRef]

55. Tempesta, T. The perception of agrarian historical landscapes: A study of the Veneto plain in Italy. Landsc. Urban Plan. 2010, 97, 258-272. [CrossRef]

56. Burton, R.J.F. Understanding Farmers' Aesthetic Preference for Tidy Agricultural Landscapes: A Bourdieusian Perspective. Landsc. Res. 2012, 37, 51-71. [CrossRef]

57. Cash, D.W.; Clark, W.C.; Alcock, F.; Dickson, N.M.; Eckley, N.; Guston, D.H.; Jäger, J.; Mitchell, R.B. Knowledge systems for sustainable development. Proc. Natl. Acad. Sci. USA 2003, 100, 8086-8091. [CrossRef]

58. Mills, J.; Ingram, J.; Dibari, C.; Merante, P.; Karaczun, Z.; Molnar, A.; Sánchez, B.; Iglesias, A.; Ghaley, B.B. Barriers to and opportunities for the uptake of soil carbon management practices in European sustainable agricultural production. Agroecol. Sustain. Food Syst. 2019, 10, 1-27. [CrossRef]

59. Leventon, J.; Schaal, T.; Velten, S.; Dänhardt, J.; Fischer, J.; Abson, D.J.; Newig, J. Collaboration or fragmentation? Biodiversity management through the common agricultural policy. Land Use Policy 2017, 64, 1-12. [CrossRef]

60. Glenk, K.; Shrestha, S.; Topp, C.F.E.; Sánchez, B.; Iglesias, A.; Dibari, C.; Merante, P. A farm level approach to explore farm gross margin effects of soil organic carbon management. Agric. Syst. 2017, 151, 33-46. [CrossRef]

61. Reed, M.S. Stakeholder participation for environmental management: A literature review. Biol. Conserv. 2008, 141, 2417-2431. [CrossRef]

62. Buanes, A.; Jentoft, S.; Maurstad, A.; Søreng, S.U.; Runar Karlsen, G. Stakeholder participation in Norwegian coastal zone planning. Ocean Coast. Manag. 2005, 48, 658-669. [CrossRef] 
63. Probst, K.; Hagmann, J.; Becker, T.; Fernandez, M. Developing a framework for participatory research approaches in risk prone diverse environments. In Proceedings of the Deutscher Tropentag, Hohenheim, Stuttgart, Germany, 11-12 October 2000; Available online: http:/ftp4.de.freesbie.org/pub/tropentag/ proceedings/2000/Full\%20Papers/Section\%20IV/WG\%20b/Probst\%20K.pdf (accessed on 30 December 2019).

64. Neef, A.; Neubert, D. Stakeholder participation in agricultural research projects: A conceptual framework for reflection and decision-making. Agric. Hum. Values 2011, 28, 179-194. [CrossRef]

65. Audouin, E.; Bergez, J.-E.; Therond, O. Participatory Methodology for Designing an Agroecological Transition at Local Level. In Agroecological Transitions: From Theory to Practice in Local Participatory Design; Springer International Publishing: Cham, Switzerland, 2019; pp. 177-206.

66. Sambell, R.; Andrew, L.; Godrich, S.; Wolfgang, J.; Vandenbroeck, D.; Stubley, K.; Rose, N.; Newman, L.; Horwitz, P.; Devine, A. Local Challenges and Successes Associated with Transitioning to Sustainable Food System Practices for a West Australian Context: Multi-Sector Stakeholder Perceptions. Int. J. Environ. Res. Public Health 2019, 16, 2051. [CrossRef]

67. Magrini, M.-B.; Martin, G.; Magne, M.-A.; Duru, M.; Couix, N.; Hazard, L.; Plumecocq, G. Agroecological Transition from Farms to Territorialised Agri-Food Systems: Issues and Drivers. In Agroecological Transitions: From Theory to Practice in Local Participatory Design; Springer International Publishing: Cham, Switzerland, 2019; pp. 69-98.

68. Ingram, J.; Dwyer, J.; Gaskell, P.; Mills, J.; de Wolf, P. Reconceptualising translation in agricultural innovation: A co-translation approach to bring research knowledge and practice closer together. Land Use Policy 2018, 70, 38-51. [CrossRef]

69. Sumberg, J.; Heirman, J.; Raboanarielina, C.; Kaboré, A. From Agricultural Research to ‘Product Development. ' Outlook Agric. 2013, 42, 233-242. [CrossRef]

70. Scott, A.; Skea, J.; Robinson, J.; Shove, E. Designing 'Interactive' Environmental Research for Wider Social Relevance; Special briefing No. 4; ESRC Global Environmental Change Programme: Brighton, UK, 1999; p. 15.

71. Agrawala, S.; Broad, K.; Guston, D.H. Integrating Climate Forecasts and Societal Decision Making: Challenges to an Emergent Boundary Organization. Sci. Technol. Hum. Values 2001, 26, 454-477. [CrossRef]

72. McBratney, A.; Field, D.J.; Koch, A. The dimensions of soil security. Geoderma 2014, 213, 203-213. [CrossRef]

73. Marr, E.J.; Howley, P. The accidental environmentalists: Factors affecting farmers' adoption of pro-environmental activities in England and Ontario. J. Rural Stud. 2019, 68, 100-111. [CrossRef] 